\title{
Natural Regeneration Dynamics of Tree Seedlings on Skid Trails and Tree Gaps Following Selective Logging in a Tropical Moist Semi-Deciduous Forest in Ghana
}

\author{
Akwasi Duah-Gyamfi ${ }^{1 *}$, Boateng Kyereh ${ }^{2}$, Kwame A. Adam ${ }^{3}$, \\ Victor K. Agyeman ${ }^{1}$, Michael D. Swaine ${ }^{4}$ \\ ${ }^{1}$ Forestry Research Institute of Ghana, Council for Scientific and Industrial Research, Kumasi, Ghana \\ ${ }^{2}$ Faculty of Renewable Natural Resources, Kwame Nkrumah \\ University of Science and Technology, Kumasi, Ghana \\ ${ }^{3}$ Ghana Timber Millers Organization, Kumasi, Ghana \\ ${ }^{4}$ Institute of Biological and Environmental Sciences, University of Aberdeen, Aberdeen, UK \\ Email: "adgyamfi@csir-forig.org.gh, kadgyamfi@hotmail.com
}

Received October $19^{\text {th }}, 2013$; revised November $21^{\text {st }}, 2013$; accepted December $23^{\text {rd }}, 2013$

\begin{abstract}
Copyright (C) 2014 Akwasi Duah-Gyamfi et al. This is an open access article distributed under the Creative Commons Attribution License, which permits unrestricted use, distribution, and reproduction in any medium, provided the original work is properly cited. In accordance of the Creative Commons Attribution License all Copyrights (C) 2014 are reserved for SCIRP and the owner of the intellectual property Akwasi Duah-Gyamfi et al. All Copyright $@ 2014$ are guarded by law and by SCIRP as a guardian.
\end{abstract}

One of the main threats to the sustainability of timber production in naturally managed forests in Ghana is insufficient regeneration of timber tree species. This study assessed regeneration success of a logged forest by comparing the species composition, diversity, density, recruitment, mortality, and growth of naturally established seedlings in 160 seedling plot samples of $50 \mathrm{~m}^{2}$ located randomly on main skid trails, secondary skid trails, felled tree gaps and unlogged parts of the same forest. The study was done within a 134-ha compartment in a selectively logged moist semi-deciduous forest in Ghana over a period of 33 months involving four enumerations. Seedlings population was initially dominated by pioneers, but after 33 months, population in all sites was dominated by non-pioneers. Seedling densities showed an increase initially in all the sites after logging, but declined after 10 months. The high seedling densities were driven by four (Albizia zygia, Ceiba pentandra, Celtis mildbraedii and Turreanthus africanus) out of the 37 species that regenerated. All four species exhibited a period of exceptionally high new seedling recruitment in the first 10 months. Diversity differed significantly among disturbance types initially, but after 33 months diversity was lower in the unlogged areas though not significant. Seedling mortality was initially greater in unlogged areas of the forest and growth rates higher in the logged areas. These results show that disturbed areas appear to be suitable sites for the regeneration of timber species following logging, although the long-term fate of trees growing on these areas remains uncertain as growth rates declined with time.

Keywords: Disturbance; Forest Succession; Ghana; Logging; Regeneration; Tropical Moist Semi-Deciduous Forest

\section{Introduction}

In most tropical countries including Ghana, selective logging with or without silvicultural treatment is the most widely adopted system for the extraction of timber from natural forests. It involves periodic entries into a given area of forest to remove selected commercial timber trees using heavy extraction machines. In some tropical areas (e.g. South-East Asia), about eight or more trees are removed per hectare at 30 - 40-year intervals (Sist et al., 2003). In Ghana, the system involves the removal of 2 - 3 trees per hectare at 40-year interval and has a relatively high minimum diameter $(50-110 \mathrm{~cm})$ for felling most species. This low intensity logging is supposed to result in less damage to the residual forest and ensure sufficient regene-

\footnotetext{
${ }^{*}$ Corresponding author.
}

ration after logging. However, the current system as currently practiced lacks any standard post-logged silvicultural practices to enhance regeneration and has often been cited as a cause for the sparse regeneration in Ghana's forests (Swaine et al., 1997).

Logging alters the forest environment by creating a heterogeneous canopy with a range of different microenvironments, such as loading bays, skid trails, logging gaps and logging roads, which differ primarily in light intensity and soil disturbance (Fredericksen \& Mostacedo, 2000; Van Rheenen et al., 2004). These changes imposed by the logging operations can lead to a change in the species composition of the disturbed forest (Brokaw \& Scheiner, 1989) following shifts in tree species composition during the progress of the post-harvest succession. In most tropical forests, this sequential species replacement is primarily due to major shifts in species relative 
abundance over time, where pioneer tree species characterized by rapid dispersal and fast growth are favored initially, colonize open areas, experience higher rates of mortality, and are replaced by non-pioneer species in the later stages of succession (Swaine \& Hall, 1988). Besides influencing the establishment of tree seedlings, logging may also trigger the growth of weeds and other competing vegetation that repress regeneration of timber trees and thereby arrest the post-harvest succession in gaps and skid trails (Fredericksen \& Mostacedo, 2000; Fredericksen \& Pariona, 2002; Dupuy \& Chazdon, 2006). In Ghana, the herbaceous weed Chromolaena odorata and more recently the invasive exotic woody plant Broussonetia papyrifera grow profusely in open areas including log landings, gaps, skid trails in logged forests, and are considered as major threats to natural regeneration and succession in the natural forests of Ghana (Agyeman, 2000; Honu \& Dang, 2000). This poses a challenge to the successful establishment of seedlings of timber trees especially when there are no post-logging silvicultural treatments as it exists in Ghana. Therefore, assessing the effects of logging gaps and associated skid trails on tree seedling recruitment, growth and mortality in logged forests, may provide insights into seedling regeneration dynamics, and can also help inform sustainable management of natural forests in Ghana.

Logging gaps and skid trails constitute about $10 \%$ of the area of a logged compartment in Ghana (Hawthorne, 1993), are disturbed heavily during logging and often show poor regeneration due to loss of topsoil. It has been suggested that logging gaps and skid trails should be a primary focus for improved regeneration in tropical forests (Heinrich, 1978; FAO, 1983). Despite their importance, natural regeneration processes in these post-logged areas have not been adequately studied in Ghana. Although earlier studies in Ghana by Hawthorne (1993), Abebrese and Kyereh (2005), and Swaine and Agyeman (2008) showed improved regeneration on skid trails and other disturbed areas few months after logging, further knowledge of the dynamics of tree species regeneration would be highly valuable. It is not known how post-logging disturbance types with different degrees of logging disturbance differ in terms of recruitment, mortality, and growth of naturally established tree seedlings, and how these variables change with time as the earlier studies did not monitor regeneration dynamics over a period of time. In this paper, we describe the dynamics of naturally regenerating seedlings over a period of 33 months involving four enumerations of permanent plots in a selectively logged tropical moist semi-deciduous forest in Ghana. In particular, our aim was to evaluate the effects of logging on changes in ecological species guild abundance, diversity, density, recruitment, mortality and growth rates of naturally regenerating tree seedlings in post-logged disturbed and unlogged areas of the same forest.

\section{Materials and Methods}

\section{Study Site}

The study was conducted in the Pra-Anum Forest Reserve $\left(6^{\circ} 15^{\prime} \mathrm{N}, 1^{\circ} 12 \mathrm{~W}\right)$ which falls within the moist semi-deciduous forest sub type in the High Forest Zone of Ghana (Figure 1). The forest has a total area of 12,332 ha, and is mostly of gentle topography with an average height of about $140 \mathrm{~m}$ above sea level. The mean annual rainfall is between 1500 and $1750 \mathrm{~mm}$, characterized by two peak rainy seasons (May-June, and October) and a mild harmattan (November to March). Mean annual

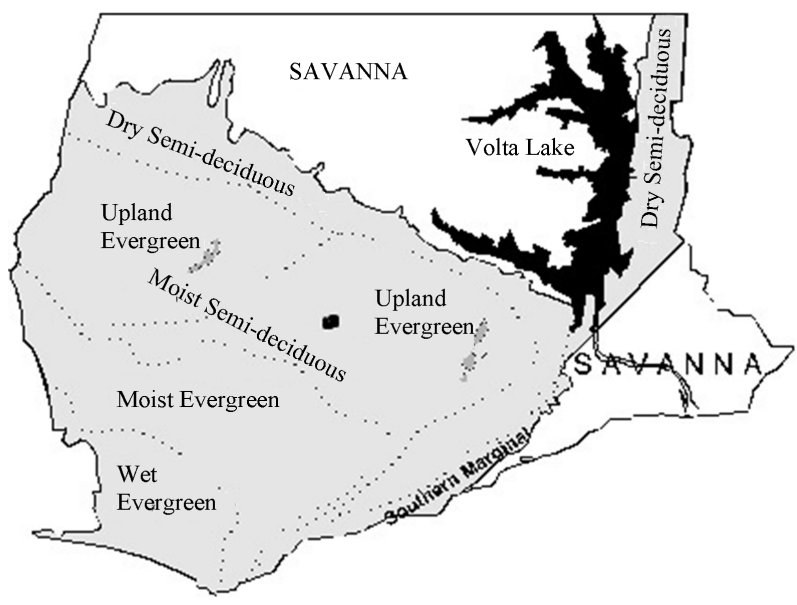

Figure 1.

Map of southern Ghana showing distribution of forest types in the High Forest Zone. The location of Pra-Anum Forest Reserve is indicated by the small black rectangle. Source: Hall and Swaine (1976).

temperature is $26.5^{\circ} \mathrm{C}$ (Hall \& Swaine, 1981). Soils of PraAnum are derived from thoroughly weathered parent materials and are primarily classified as forest oxysol-ochrosol intergrades (Brammer, 1962). The forest structure is characterized by very tall trees of about $50 \mathrm{~m}$ in a mixture of deciduous and evergreen species of varying proportions (Hall \& Swaine, 1981). The most common species in the reserve are Celtis mildbraedii, Cylicodiscus gabunensis, Triplochiton scleroxylon and Turreanthus africanus. The reserve has served as a timber production area and silvicultural research station since 1954.

\section{Experimental Design}

The specific experimental area was a 134 ha compartment (Compartment 4 in the Research Working Circle) of Pra-Anum Forest Reserve that was selectively logged by Swiss Lumber Company in July and August 2000, using chainsaw felling and extraction of logs with rubber-tired skidders. Selective logging was limited to commercial tree species currently exploited in Ghana using minimum felling diameter (MFD) limits of 50 $110 \mathrm{~cm}$ dbh, depending on species and removing 2 - 3 trees per hectare. For trees $\geq 70 \mathrm{~cm} \mathrm{dbh}$, the five most abundant species in the research compartment are Triplochiton scleroxylon (Sterculiaceae), 226 trees; Celtis mildbraedii (Ulmaceae), 197 trees; Cylicodiscus gabunensis (Fabaceae), 109 trees; Turreanthus africanus (Meliaceae), 86 trees and Ceiba pentandra (Bombacaceae), 79 trees.

In August 2000, immediately following harvesting, three disturbance categories created from the logging activities in the compartment namely, main skid trail (MST), secondary skid trail (SST) and felled tree gap (FG), and unlogged areas of the forest unaffected by the recent logging activities (UNL) were mapped, using a tape and compass. Subsequently, 40 randomly-located sample plots were laid in each of MST, SST, FG and UNL, giving a total of 160 permanent sample plots within the entire compartment. In order that the sampled plots were representative of the disturbance categories, main skid trail and secondary skid trail plots were located linearly along the trails and were $10 \mathrm{~m} \times 5 \mathrm{~m}$; felled tree plots were laid in the direction of tree fall with the stump as the base and measured $25 \mathrm{~m} \times 2 \mathrm{~m}$. Samples in the unlogged areas of the forest were also $25 \mathrm{~m} \times 2 \mathrm{~m}$. 


\section{Characterization of Disturbance Types}

The disturbance categories were characterized in terms of light availability, measured indirectly as canopy openness, and soil disturbance condition. Hemispherical photos were taken in August 2000 and re-taken December 2012 using a Nikon F2 digital camera with a sigma $8 \mathrm{~mm}$ hemispherical lens, mounted on a tripod, to determine canopy openness. Photos were taken with an overcast sky and at a height of $1 \mathrm{~m}$ in the center of each plot. The photographs were analyzed with imaging software: Winphot 5.0 (Ter Steege, 1996) to determine canopy openness. Soil condition was assessed visually in each plot and assigned to one of four categories: 1 (topsoil undisturbed), 2 (topsoil slightly removed or displaced), 3 (topsoil largely removed, rutted, no puddles) and 4 (topsoil removed, deeply rutted and puddle).

\section{Plant Measurements}

Following plot establishment (August 2000), post-logging seedling recruits were enumerated on four occasions at approximately $0.5,4.2,10$ and 33 months (mo) after logging ceased in the compartment. At each enumeration, each tree seedling was identified to seedling level and tagged, mapped within the sample plot and its vertical height from the ground to the apical bud measured with a meter tape or telescopic rod where necessary. In subsequent re-enumerations, surviving seedlings were re-measured for height, dead or missing seedlings recorded, and new seedlings identified, tagged, mapped and their heights measured. Species nomenclature and shade tolerance guild follow Hawthorne (1995) classification: Pioneers (P) establish and survive only in high light conditions, have very fast growth rates but higher mortality than other groups; Non-Pioneer light demanders (NPLD) establish in shade, however, further growth requires higher light; NonPioneer shade bearers (NPSH) establish and grow in shade, often with high densities, and lower mortality in shade. Because most species in some plots were represented by only a few individuals, seedlings were grouped for some analyses into the ecological species guilds in accordance with Swaine et al. (1987).

\section{Data Analysis}

In each disturbance category, the number of seedlings and species within each $50 \mathrm{~m}^{2}$ plot at each census was counted and recorded. These data were used to describe several attributes of the seedling community of disturbance categories and unlogged areas of the forest, including species richness, density and relative density of species. Chi-squared tests of independence were used to determine if the distribution of seedlings among ecological species guild changed within sites over the 33-month study period. Sample-based rarefaction (Gotelli \& Colwell, 2001), was used to compare species richness among sites at the beginning and end of the study period, by constructing species accumulation curves after 200 randomizations of sample order with the program EstimateS (version 8, Colwell, 2006). Differences in diversity among disturbance categories were evaluated by analyzing the Shannon-Wiener index $\left(H^{\prime}\right)$ provided by Estimates.

To establish the importance of mortality and recruitment in explaining changes through time in the relative abundance of ecological species guilds, we determined the mortality and recruitment rates between successive census periods. Mortality rates, m, were calculated using Equation (1) derived by (Sheil et al., 1995),

$$
m=1-\left(\frac{N_{t}}{N_{o}}\right)^{\frac{1}{t}}
$$

where $N_{t}$ is the number of seedlings alive at the end of the measurement interval, $t$, and $N_{0}$ is the number of seedlings at the beginning of the interval. Recruitment rates, $r$, were calculated in a similar way (Sheil et al., 2000) as,

$$
r=1-\left(1-\frac{n_{r}}{N_{t}}\right)^{\frac{1}{t}}
$$

where $n_{r}$ is the number of recruits during the period, and $N_{t}$ and $t$ are as above. The height data was used to estimate relative height growth rate (RHGR) as height growth per unit plant height in $\mathrm{cm} \cdot \mathrm{cm}^{-1} \cdot \mathrm{mo}^{-1}$. Differences in canopy openness, density and, growth, recruitment and mortality rates among disturbance categories were analyzed using analysis of variance (ANOVA) after data had been screened for conformity to the assumptions of normality and homogeneity of variance. When these assumptions were not valid, even after data transformation, the Kruskal-Wallis test was used. Where the tests indicated significant differences among land use types, means were contrasted with post hoc Tukey HSD tests and for non-parametric data, Mann-Whitney tests was used to compare medians.

Detrended correspondence analysis (DCA) was used to explore the variation of floristic composition across sites. Abundance of seedlings in the four censuses for each site was entered in the DCA which was executed in PC-ORD for Windows (McCune \& Mefford, 1997). Statistical analysis was carried out using MINITAB (version 14).

\section{Results}

\section{Site Characteristics}

Canopy openness immediately after harvesting ranged from $4.9 \%$ in the unlogged forest to $14.7 \%$ in the felled tree gap (Table 1). There were no significant differences between skid trails and felled tree gaps immediately after logging, but the openness of these disturbed areas was significantly $(P<0.05)$ higher than the unlogged forest.

The distribution of soil disturbance categories amongst the forest types is shown in Figure 2. All the samples in unlogged parts of the forest had relatively undisturbed topsoil, whilst the majority of felling gaps and secondary skid trails were only slightly disturbed. The main skid trail samples, used several times for the transport of logs, were mostly heavily disturbed with deeply rutted and puddled soil.

\section{Shift in Ecological Guild Distribution, Species Composition and Diversity}

Across all sites the distribution of seedling abundance by ecological species guild changed significantly throughout the study period (Table 2). In general, relative abundance of non-pioneers increased significantly over the period from $0.5 \%$ to $59 \%$, at the expense of the relative abundance of pioneers, which decreased in the same period from $98 \%$ to $2 \%$. Pioneers were much more abundant initially on skid trails and tree-fall gaps and after 33 months pioneer population had significantly 


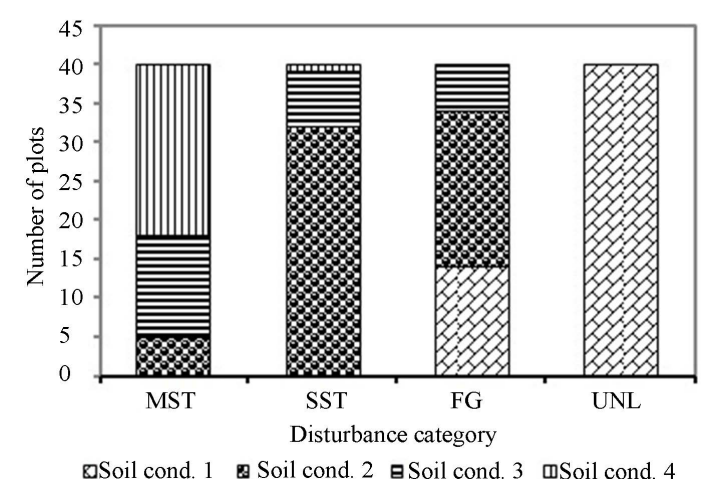

Figure 2.

Soil conditions (cond.) in disturbance categories.

Table 1.

Mean canopy openness $( \pm \mathrm{SE})$ in four disturbance categories in a moist semi-deciduous forest in Ghana.

\begin{tabular}{ccc}
\hline \multirow{2}{*}{ Disturbance category } & \multicolumn{2}{c}{ Canopy openness (\%) } \\
\cline { 2 - 3 } & $2000(\mathrm{n}=40)$ & $2012(\mathrm{n}=10)$ \\
\hline Felling gap & $14.7(0.86)^{\mathrm{a}}$ & $13.9(0.51)^{\mathrm{a}}$ \\
Main skid trail & $14.5(0.90)^{\mathrm{a}}$ & $13.6(0.44)^{\mathrm{a}}$ \\
Secondary skid trail & $14.1(1.07)^{\mathrm{a}}$ & $9.5(1.43)^{\mathrm{b}}$ \\
Unlogged forest & $4.9(0.44)^{\mathrm{b}}$ & $4.3(0.41)^{\mathrm{c}}$ \\
\hline
\end{tabular}

Note: Within each year, values followed by a different letter are significantly. different $(P<0.05)$.

declined with the lowest abundance (2\%) in the unlogged forest. With the decline in pioneers, the non-pioneers became more numerous on all sites 33 months after logging with highest relative abundances of $59 \%$ and $53 \%$ recorded for NPSH on main skid trail and the unlogged areas respectively. Contingency table evaluations using chi-squared test of independence found significant differences in frequency distribution of seedlings of the various guilds in all sites over the period $(P<0.001$, in all cases).

Species composition of the initial pioneer community was predominantly $C$. pentandra and $R$. heudelotti. The two species represented more than $90 \%$ and $80 \%$ of the initial seedling population on skid trails and tree-fall gaps respectively, but less than $30 \%$ in the closed canopy forest. A small-stature pioneer $C$. patens was common and particularly numerous in the first measurement. Among the non-pioneers, C. mildbraedii was common in all sites during the final census. Other common non-pioneers included the shade-bearers T. africanus, N. papaverifera and the non-pioneer light-demander A. zygia. These species attained high numbers at different periods indicating differences in recruitment patterns. Other species had few or poor regeneration: $T$. scleroxylon, a common species in the compartment was not recorded until at the third enumeration; $C$. gabunensis, also had poor regeneration.

DCA showed that the seedling composition of the sites, initially dominated by pioneers, was distinct from that at the end of the study, and was depicted by the wide separation of these seedling communities on the first axis of the DCA (Figure 3). The first axis of the DCA, which explained $46.3 \%$ of the total variation in species data, appeared to be associated with successional development and separated sites by census period with the initial pioneer dominated census at one end while later censuses dominated by non-pioneers grouping together.

Species accumulation curves followed an asymptotic pattern in all sites, and showed that species richness was higher in the unlogged area at the initiation of the study (Figure 4). By the

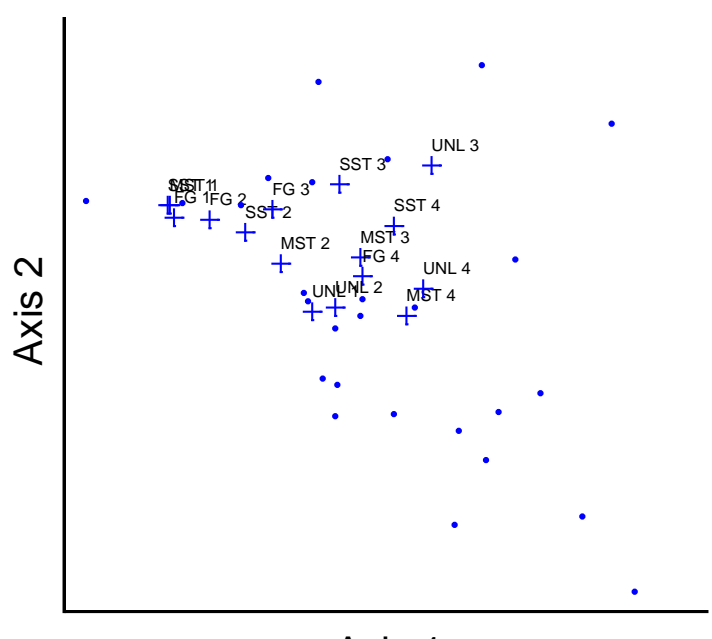

Axis 1

Figure 3.

Detrended correspondence analysis of 30 tree species that had a minimum of eight seedlings in at least one of the censuses in the disturbance categories. Each species is represented by a small circle, and the position of each disturbance category in ordination space is shown with a cross. The eigenvalue for axis 1 was 0.406 and for axis 2 was 0.100 .
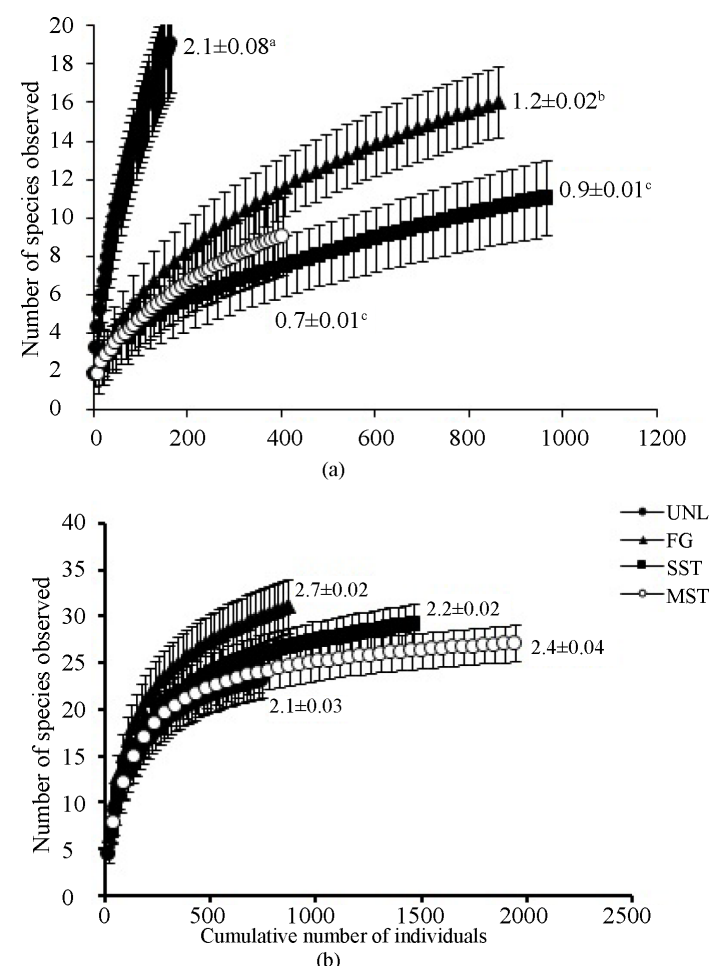

Figure 4.

Species accumulation curves $(x \pm 1 \mathrm{SD})$ for tree seedlings present in unlogged forest area, tree gap, secondary skid trail and main skid trail at (a) the beginning and (b) completion of study in a moist semi-deciduous forest in Ghana. 
Table 2.

Relative densities of seedlings of tree species in disturbance categories at 0.5, 10 and 33 mo following selective logging in a moist forest in Ghana.

\begin{tabular}{|c|c|c|c|c|c|c|c|c|c|c|c|c|c|c|}
\hline \multirow[b]{3}{*}{ Species } & \multirow[b]{3}{*}{ Family } & \multirow[b]{3}{*}{ Guild } & \multicolumn{4}{|c|}{ Relative density (\%) } & \multicolumn{4}{|c|}{ Relative density (\%) } & \multicolumn{4}{|c|}{ Relative density (\%) } \\
\hline & & & \multicolumn{4}{|c|}{ Census 1 (0.5 mo) } & \multicolumn{4}{|c|}{ Census 3 (10 mo) } & \multicolumn{4}{|c|}{ Census 4 (33 mo) } \\
\hline & & & MST & SST & FG & UNL & MST & SST & FG & UNL & MST & SST & FG & UNL \\
\hline Ceiba pentandra & Bombacaceae & $\mathrm{P}$ & 75.67 & 69.05 & 57.84 & 28.92 & 15.13 & 22.6 & 37.33 & 3.29 & 4.22 & 6.31 & 11.47 & 0.67 \\
\hline Ricinodendron heudelotii & Euphorbiaceae & $\mathrm{P}$ & 20.6 & 24.74 & 29.04 & 3.01 & 1.52 & 4.42 & 7.03 & 0.4 & 0.31 & 0.41 & 2.34 & - \\
\hline Distemonanthus benthamianus & Fabaceae & $\mathrm{P}$ & 0.25 & - & - & 0.6 & - & - & - & 0.07 & 0.62 & 0.27 & 0.33 & 0.67 \\
\hline Terminalia superba & Combretaceae & $\mathrm{P}$ & - & - & - & 0.6 & 0.93 & 0.29 & 1.46 & 0.07 & 0.77 & 0.41 & 1 & - \\
\hline Cedrela odorata & Meliaceae & $\mathrm{P}$ & - & - & - & - & 7.3 & 3.96 & 8.55 & 6.32 & 5.04 & 2.88 & 10.47 & 0.27 \\
\hline Cleistopholis patens & Annonaceae & $\mathrm{P}$ & 1.24 & 3.31 & 4.12 & - & 0.93 & 1.9 & 3.8 & 0.86 & 0.67 & 1.23 & 3.34 & 0.27 \\
\hline Triplochiton scleroxylon & Sterculiaceae & $\mathrm{P}$ & - & - & - & - & 1.19 & 0.11 & 0.32 & 0.2 & 1.75 & 0.27 & 0.78 & 0.13 \\
\hline Milicia excelsa & Moraceae & $\mathrm{P}$ & 0.25 & - & - & - & 5.46 & 7.82 & 13.13 & 0.07 & 2 & 2.88 & 4.45 & - \\
\hline Alstonia boonei & Apocynaceae & $\mathrm{P}$ & - & - & - & - & 1.58 & 1.96 & 1.04 & - & 1.34 & 3.02 & 0.67 & - \\
\hline Canarium scweinfurthii & Burseraceae & $\mathrm{P}$ & 0.25 & - & 0.56 & - & - & - & 0.05 & - & - & - & 0.11 & - \\
\hline Nauclea diderrichii & Rubiaceae & $\mathrm{P}$ & - & - & - & - & 2.98 & 0.54 & 0.31 & - & 2.37 & 0.35 & 0.11 & - \\
\hline Petersianthus macrocarpus & Lecythidaceae & $\mathrm{P}$ & - & - & - & - & - & - & 0.47 & - & - & - & 0.89 & - \\
\hline Bombax buonopozense & Bombacaceae & $\mathrm{P}$ & - & - & - & - & 0.04 & - & - & - & 0.05 & - & - & - \\
\hline Daniellia ogea & Fabaceae & $\mathrm{P}$ & - & - & - & - & - & 0.03 & - & - & - & - & - & - \\
\hline Mansonia altissima & Sterculiaceae & NPLD & - & 0.1 & 1.89 & 24.73 & 0.61 & 0.13 & 1.46 & 1.19 & 1.9 & 1.37 & 5.46 & 1.6 \\
\hline Antiaris toxicaria & Moraceae & NPLD & - & - & 0.44 & 3.01 & 0.5 & 0.75 & 0.78 & 1.58 & 0.93 & 1.85 & 2.12 & 4.8 \\
\hline Piptadeniastrum africanum & Fabaceae & NPLD & - & 0.42 & - & 3.01 & - & 0.38 & 0.1 & 0.59 & - & 0.62 & 0.33 & 1.34 \\
\hline Albizia zygia & Fabaceae & NPLD & 0.5 & 0.42 & 0.11 & 2.41 & 13.37 & 31.13 & 7.76 & 52.96 & 9.63 & 30.73 & 7.35 & 20.59 \\
\hline Sterculia rhinopetala & Sterculiaceae & NPLD & - & - & 0.11 & 2.41 & 0.79 & 0.51 & 0.36 & 1.85 & 2.42 & 2.67 & 0.22 & 9.49 \\
\hline Blighia sapida & Sapindaceae & NPLD & - & - & 0.11 & 1.2 & 0.4 & 0.11 & 0.1 & 0.13 & 0.93 & 0.48 & 0.45 & 0.67 \\
\hline Albizia ferruginea & Fabaceae & NPLD & - & - & - & 0.6 & - & - & - & 0.07 & - & - & - & - \\
\hline Entandrophragma angolense & Meliaceae & NPLD & - & - & - & 0.6 & - & - & 0.05 & - & 3.24 & 0.62 & 0.89 & 2.27 \\
\hline Pterygota macrocarpa & Sterculiaceae & NPLD & - & - & 0.11 & 0.6 & - & 0.08 & 0.32 & 0.07 & 1.39 & 0.48 & 1.45 & 1.07 \\
\hline Aningeria robusta & Sapotaceae & NPLD & - & - & - & - & - & 0.03 & 0.1 & - & - & 1.03 & 1.56 & 1.07 \\
\hline Khaya spp. & Meliaceae & NPLD & - & - & - & - & - & 0.27 & - & - & 0.15 & 0.14 & 0.11 & 1.07 \\
\hline Cola gigantean & Sterculiaceae & NPLD & - & - & 0.11 & - & 0.18 & - & 0.05 & - & 0.62 & - & 0.33 & 0.4 \\
\hline Albizia adianthifolia & Fabaceae & NPLD & - & - & 0.11 & - & 0.11 & - & - & 0.07 & 0.05 & - & - & \\
\hline Sterculia oblonga & Sterculiaceae & NPLD & - & 0.1 & - & - & 0.14 & 0.03 & 0.1 & - & 0.15 & 0.07 & 4.68 & - \\
\hline Pycnanthus angolensis & Myristicaceae & NPLD & - & - & - & - & - & - & - & - & - & 0.07 & - & - \\
\hline Celtis mildbraedii & Ulmaceae & NPSH & 0.74 & 1.14 & 1.67 & 15.66 & 14.16 & 6.88 & 8.65 & 5.5 & 14.26 & 18.24 & 22.16 & 10.43 \\
\hline Nesogordonia papaverifera & Sterculiaceae & NPSH & 0.5 & 0.42 & 2.67 & 9.04 & 14.41 & 1.42 & 3.34 & 2.83 & 22.54 & 4.25 & 8.8 & 8.02 \\
\hline Strombosia glaucescens & Olacaceae & NPSH & - & 0.1 & 0.44 & 1.2 & 0.29 & 0.08 & 0.26 & 0.07 & - & 0.34 & 0.45 & 1.34 \\
\hline Turreanthus africanus & Meliaceae & NPSH & - & - & 0.67 & 1.2 & 16.68 & 13.58 & 0.89 & 17.92 & 21.26 & 18.38 & 6.68 & 33.16 \\
\hline Hymenostegia afzelii & Fabaceae & NPSH & - & - & - & 0.6 & 0.11 & 0.96 & 1.77 & 0.73 & - & 0.14 & 0.11 & 0.27 \\
\hline Dialium aubrevillei & Fabaceae & NPSH & - & 0.1 & - & 0.6 & - & 0.03 & - & - & 0.1 & 0.35 & - & 0.13 \\
\hline Cylicodiscus gabunensis & Fabaceae & NPSH & - & 0.1 & - & - & 1.19 & - & - & 3.16 & 1.29 & - & 0.22 & 0.27 \\
\hline Guarea cedrata & Meliaceae & NPSH & - & - & - & - & - & - & 0.42 & - & - & 0.14 & 0.67 & - \\
\hline
\end{tabular}


end of the study, curves had reached their asymptotes and levelled off indicating that the area sampled was large enough to estimate the total number of species in each site. Species richness increased most in the skid trails and tree gaps, and rose slightly in the unlogged area. Species diversity estimated by the Shannon-Wiener index increased in all four sites, rising most on the skid trails and tree-fall gap because of substantial increases in number of species recorded with time (Figure 4). Initially, species diversity was significantly different among sites $(F=4.3$, d.f. $=3, P=0.027)$ with the unlogged area being the most diverse followed by the tree-fall gap, secondary skid trail with the main skid trail being the least diverse. However, after 33 months diversity indexes appeared slightly higher in all the disturbed areas (compared to the unlogged area (Figure 4), though not significant ( $F=1.6$, d.f. $=3, P=0.240$ ).

\section{Mortality and Recruitment Patterns}

For all ecological species guild, recruitment rate across disturbance categories was higher than mortality rate for the first and second measurement interval except for mortality rate of pioneers in the unlogged area which was higher compared to recruitment rate, the reason for the significantly lower (negative) net gain rate recorded for only pioneers during that period (Figure 5(b)). For recruitment and net gain rates there were significant interactions between ecological species guild and disturbance categories (recruitment: $\mathrm{F}=5.58$, d.f. $=2$ and $P<$
0.001 and net gain rate: $\mathrm{F}=2.61$, d.f. $=6$ and $P<0.05$ ). Pioneers had a significantly higher recruitment rate $(P<0.05)$ than the other two groups, and logged areas had significantly higher recruitment rates $(P<0.05)$ than unlogged areas. Mortality rates were significantly higher for pioneers than the other groups across all disturbance types (Figure 5(a)). For the latter censuses, recruitment rates were significantly higher $(P<0.05)$ for the non-pioneers than pioneers across all sites with highest rates in unlogged areas (Figure 5(c)). Net gain rates were significantly higher $(P<0.05)$ and positive for non-pioneers across all disturbance categories while pioneers had significantly lower net gain rates across all sites (Figure 5(d)).

\section{Seedling Density}

Across all sites seedling densities increased steadily and peaked at $10 \mathrm{mo}$, thereafter declined till the termination of the study (Table 3). Seedling density was highest in secondary skid trail for most part of the study period, and was much lower in the unlogged forest. Among the logged sites, median densities were lower in gaps compared to skid trails but were less variable than those on skid trails. The period recorded for maximum density attained by most species varied during the study. At 0.5 mo, density of the pioneer species, $C$. pentandra, was highest at all sites, about 2.5 and 13 times higher than densities of other common species for that period such as $R$. heudelotii and $C$. mildbraedii, respectively, on secondary skid trails. For most
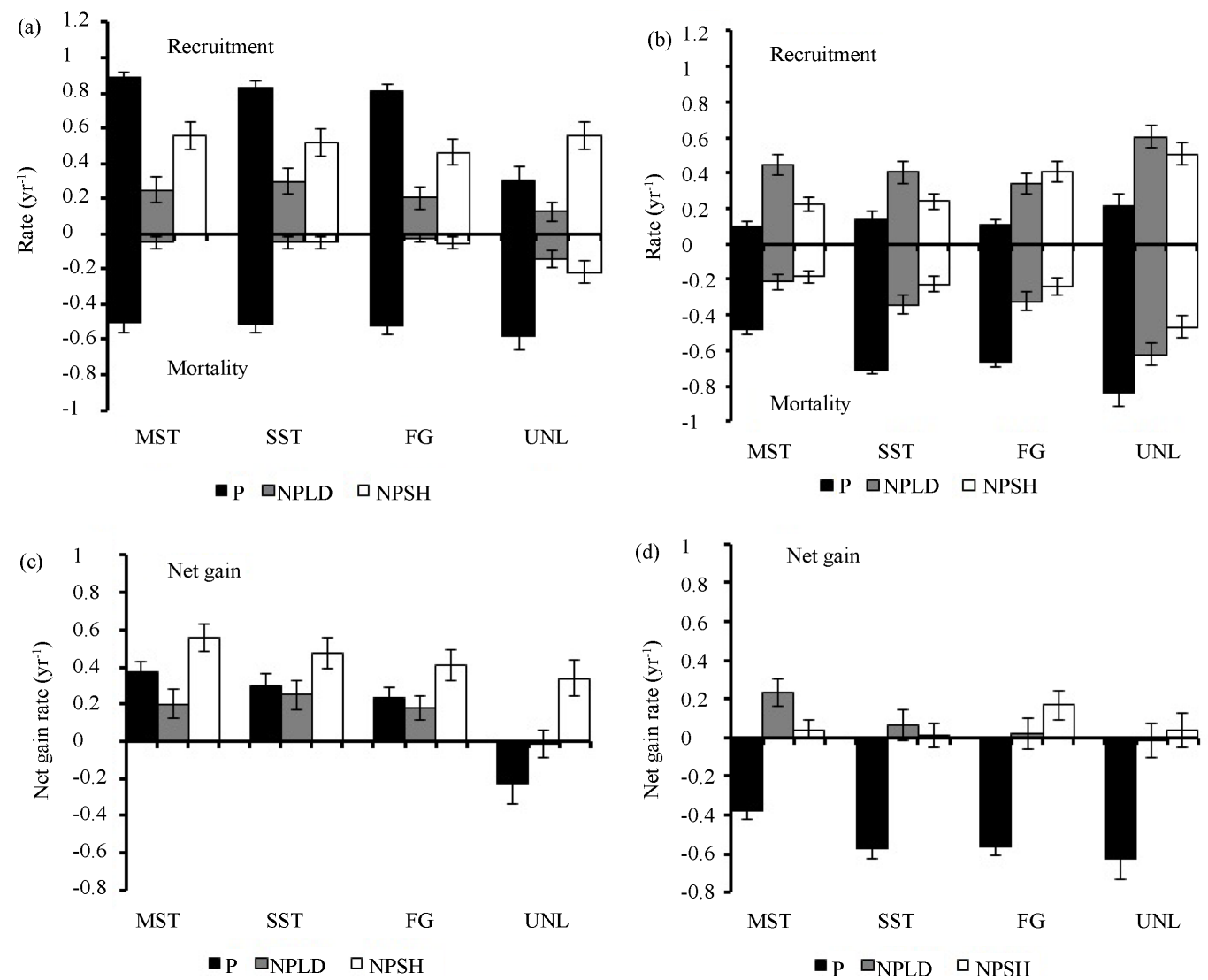

Figure 5.

Mean mortality, recruitment and net gain rates for pioneer, non-pioneer light demander and non-pioneer shade bearer across disturbance types between the measurement intervals 1 and 2 (a, b) and 3 and 4 (c, d). Mortality rates are represented as negative values. The net gain rate is the sum of the recruitment and (negative) mortality rates. 
Table 3.

Seedling density at 0.5, 4.2, 10 and 33 mo after logging in a tropical forest in Ghana.

\begin{tabular}{ccccc}
\hline \multirow{2}{*}{$\begin{array}{c}\text { Disturbance } \\
\text { category }\end{array}$} & \multicolumn{4}{c}{ Months after logging } \\
\cline { 2 - 5 } & $0.5 \mathrm{mo}$ & $4.2 \mathrm{mo}$ & $10 \mathrm{mo}$ & $33 \mathrm{mo}$ \\
\hline Main skid trail & $0.13(0-2.60)^{\mathrm{a}}$ & $0.34(0.10-9.16)^{\mathrm{a}}$ & $0.96(0.28-10.20)^{\mathrm{a}}$ & $0.62(0.10-5.49)^{\mathrm{a}}$ \\
Secondary skid trail & $0.32(0-2.75)^{\mathrm{b}}$ & $0.89(0.10-7.94)^{\mathrm{b}}$ & $1.36(0.25-19.86)^{\mathrm{b}}$ & $0.49(0.04-7.68)^{\mathrm{a}}$ \\
Felled tree gap & $0.28(0.07-1.95)^{\mathrm{b}}$ & $0.49(0.08-3.20)^{\mathrm{c}}$ & $0.81(0-2.85)^{\mathrm{a}}$ & $0.28(0.02-1.72)^{\mathrm{b}}$ \\
Unlogged forest & $0.03(0-0.47)^{\mathrm{c}}$ & $0.06(0-0.70)^{\mathrm{d}}$ & $0.32(0-6.97)^{\mathrm{c}}$ & $0.27(0-0.90)^{\mathrm{b}}$ \\
\hline
\end{tabular}

species, densities peaked at 10 mo with A. zygia and C. pentandra dominant on skid trails, and A. zygia in unlogged areas. By 33 mo, densities of pioneers had declined with the nonpioneer shade bearers $C$. mildbraedii and $N$. papaverifera common in all sites and T. africanus highest in unlogged areas. There were significant differences $(P<0.001)$ among sites in total seedling density over the entire period of the study; for the beginning and end of the study period $\left(\mathrm{KW} \chi^{2}(3)=56.40\right.$ and 22.97, respectively, $P<0.001$ in both cases).

\section{Seedling Growth}

Thirty-three months after the start of the study, the tallest seedlings of most species were located in the logged areas and the smallest were situated in the unlogged area. At the beginning of the study, there was little difference in seedling height among the sites, and this difference became apparent after 1.5 mo for $R$. heudelotti, 1.6 mo for M. altissima, 1.8 mo for $N$. papaverifera and 4.5 mo for C. mildbraedii.

The relative height growth rate for all species was significantly $(P<0.05)$ higher in logged forest (secondary skid trail and main skid trail at the beginning and end of the study respectively) and lowest in unlogged area in all cases (Figure 6). Across sites, pioneers grew faster than non-pioneers. Among the common species that survived to the end of the study, the pioneer species $C$. pentandra and $R$. heudelotti had the highest RHGR. Over the period, estimated mean RHGR of $C$. pentan$d r a$ and $R$. heudelotti were $0.11 \mathrm{~cm} \cdot \mathrm{cm}^{-1} \mathrm{mo}^{-1} \pm 0.003$ and 0.10 $\mathrm{cm} \cdot \mathrm{cm}^{-1} \cdot \mathrm{mo}^{-1} \pm 0.005$ in main and felled tree gap respectively. The RHGR of common non-pioneers $C$. mildbraedii and $N$. papaverifera $0.06 \mathrm{~cm} \mathrm{~cm}^{-1} \cdot \mathrm{mo}^{-1} \pm 0.011$ and 0.04 $\mathrm{cm} \cdot \mathrm{cm}^{-1} \cdot \mathrm{mo}^{-1} \pm 0.003$ respectively in the tree gap. There was a decrease in the mean RHGR of species in all the sites.

\section{Discussion}

Logging had a positive impact on the regeneration of seedlings as the initial establishment and subsequent growth of seedlings increased with increasing soil disturbance and canopy openness. However, this initial increase was mostly due to pioneer species notably $C$. pentandra. This species is light-seeded, shade-intolerant that would be expected to benefit from the soil disturbance caused by logging machinery as well as the increased light from canopy removal. The present result showed that recruitment and density of seedlings, especially pioneers, over the first 10 mo after logging was substantially higher in skid trails and tree gaps than in unlogged areas of the forest. Our results support the widely held view that disturbance favours pioneers as observed in tropical forests (Fredericksen \& Mostacedo, 2000; Fredericksen \& Pariona, 2002; Sist and Nguyen-Thé, 2002; Van Rheenan et al., 2004; Gourlet-Fleury et al., 2004; Swaine \& Agyeman, 2008). Even though higher

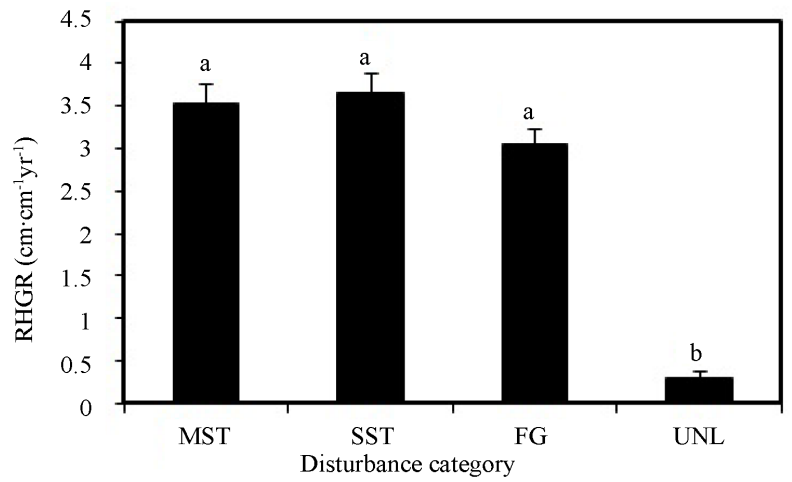

(a)

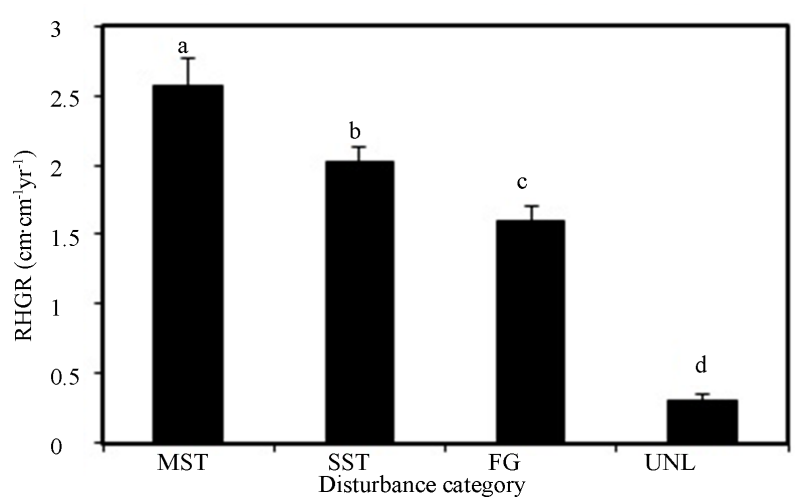

(b)

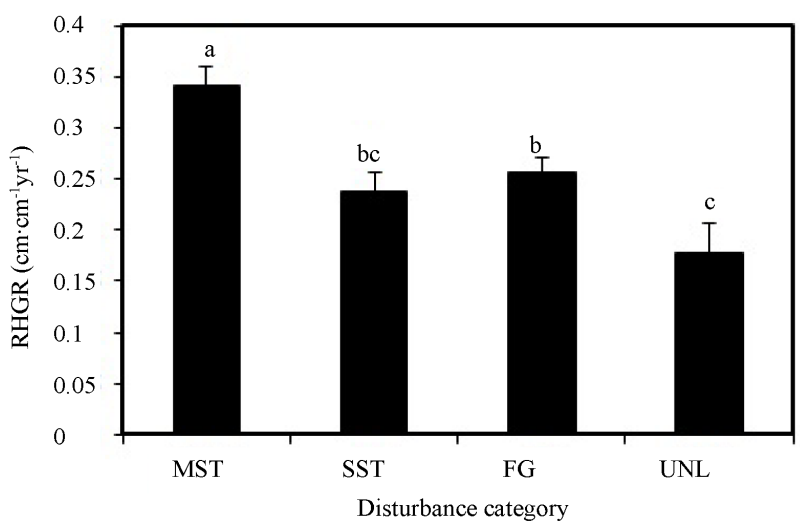

(c)

Figure 6.

Mean relative height growth rate of seedlings from (a) 0.5 to $4.5 \mathrm{mo}$ (b) 4.5 to $10 \mathrm{mo}$ and (c) 10 to $33 \mathrm{mo}$ in areas disturbed by logging and unlogged areas in a tropical moist forest in Ghana. Treatments with different letters are significantly different at $P<0.05$. 
soil compaction can impede the establishment of seedlings (Pinard et al., 2000), greater canopy openness, and soil disturbance (Denslow, 1995; Dickinson \& Whigham, 1999), and the intensity of logging (Cornell, 1978; Sheil \& Burslem, 2003) can favour tree seedling regeneration. For instance, least disturbed areas with upturned soil from the churning action of skidder, may facilitate establishment of small-seeded, light demanding tree species (Putz, 1983). This is possible especially on the secondary skid trails where the lesser degree of soil mechanical disturbance from single passage of skidder could offer favourable substrate conditions for seedling establishment.

Changes in species guild composition during the course of succession was an indication of shifts in the relative abundance or dominance of the ecological species guilds of the seedling community within the sites from pioneers at the beginning of the study to non-pioneers at the end of the study. This shift in dominance from the more light demanding pioneers to the shade-tolerant non-pioneers may be a reflection of the intrinsic responses of the guilds to changes in the microenvironment of the sites with time, particularly light. Initially, the high amount of light resulting from the logging operations may have favored the regeneration of pioneers while at the latter stages the reduced irradiance and temperature may have favoured the non-pioneers especially the shade bearers. A possible explanation for this observation is that gaps created by logging in tropical forests could be potentially occupied by both pioneer and non-pioneer tree species; however, the species with inherently long lifetimes will gradually replace the short-lived ones (Kuusipalo et al., 1996). Similar changes in seedling composition were observed in a Brazillian rain forest by Gomes et al., (2003) who reported that in a forest undergoing successional change, understory shade tolerant populations become more common as the canopy recovers. Detrended correspondence analysis provided further evidence that composition of the seedling communities became similar over time. This may have been accounted for by the intact forest surrounding our sites providing readily supply of seeds for the recruitment of seedlings over time but declining environmental conditions within the sites, especially reduction in light levels, may have influenced the dominance of ecological species guilds with the passage of time. A similar explanation could be offered for the increase in diversity of the logged areas to comparable but slightly higher values than the unlogged areas by 33 mo. As expected, in the first census richness was higher in the unlogged forest areas than in both skid trails and gaps. Over time, skid trails and gaps showed higher richness and diversity than in the unlogged forest because of the in-growth of new species, mostly pioneer species that are uncommon in unlogged areas (Felton et al. 2006).

Seedling density rose sharply and declined over time in all sites as previously found in other studies (Abebrese \& Kyereh, 2005; Capers et al., 2005). Initial high seedling density observed in skid trails and gaps suggests enhanced regeneration or recruitment to these sites following logging, as evidenced by the higher net gain rates. The higher recruitment of fast growth pioneers, expressed by their high relative density at the initial stages could have created an environment where competition was much higher promoting higher mortality rates at the same time. Decrease in seedling density during the latter part of the study could have resulted at least in part from declining light levels which appeared to be important in reducing the recruitment and density of seedlings especially pioneers. Decline in density of pioneers is a reflection of the imbalance between recruitment and mortality-decreasing recruitment rate and increasing mortality rate-during the study period. As a consequence of higher mortality rates and lower recruitment, density of pioneers decreased in the sites, inverting the tendency observed during the first 10 mo when density increased across all sites. This was explicitly reflected at 33 mo where only pioneers had a negative net gain rate. A similar trend was observed in the non-pioneers, however, the effect of mortality rate over recruitment was less than in pioneers. Consequently, after 33 mo density of non-pioneers was higher than pioneers, hence a positive net gain rate at 33 mo. Similar effects for recruitment, mortality, and plant density have been reported before in natural and artificial gaps (e.g. Dupuy \& Chazdon, 2006; D’Oliveira \& Ribas, 2011).

Growth rates were significantly higher in skid trails and gaps than unlogged areas throughout the study. However, by 33 mo growth rates had reduced by over $90 \%$ and $40 \%$ of the initial rates in the logged and unlogged areas respectively. It seems that the initial soil disturbance in combination with high postlogging light availability associated with the disturbed sites did not negatively affect the initial growth of seedlings. Our observations concur with other studies in the tropics (e.g. Fredericksen \& Mostacedo, 2000; Van Rheenen et al., 2004). The decrease in growth rate across the disturbance types suggests the need of some silvicultural treatment to allow the maintenance of high growth rates. Although the influence of competing vegetation on seedling regeneration was not determined in this study, observations on the study plots and results from similar studies in the tropics point out that, competing vegetation may be one reason for the observed decrease in growth rate (Fredericksen \& Mostacedo, 2000; Honu \& Dang, 2000). In Ghana, the invasive $C$. odorata has been shown to repress regeneration in gaps and in open fields (Honu \& Dang, 2000). Low light availability may also partially account for the decrease in growth rate (Van Rheenen et al., 2004).

\section{Conclusion}

We conclude that the present study demonstrates some beneficial effects of logging disturbance on natural regeneration at least for the first three years. Logged forest areas differed from unlogged areas in terms of seedling recruitment, density, growth rate and mortality. The contrasts were due mostly to the rapid recruitment and fast growth of pioneers in skid trails and tree gaps. However, the sparse or lack of regeneration of other species in the compartment regardless of soil disturbance or light environment created by logging is worrying and indicates the need for improvements or silvicultural interventions in the harvesting operations currently practiced in Ghana. The decline in relative height growth rate shows one of the effects which can be achieved by silvicultural treatments (weeding, liberation thinnings, etc.) as employed in the Malayan Uniform System, or the Tropical Shelterwood System, which reduces mortality rates and secures tree regeneration.

\section{Acknowledgements}

Financial support for the research was provided by the University of Aberdeen, the British Ecological Society, the Tropenbos International and the International Tropical Timber Organization. We are grateful to Kwaku Asumadu, Peter Amoako, Vincent Berko and Dominic Bosompem for tireless 
fieldwork. We also thank the Forestry Research Institute of Ghana for logistic support.

\section{REFERENCES}

Abebrese, I. K., \& Kyereh, B. (2005). Regeneration of timber species following selective logging in a moist semi-deciduous forest in Ghana. Ghana Journal of Forestry, 17 \& 18, 20-35.

Agyeman, V. K. (2000). Natural regeneration on tropical timber species under Broussonetia. papyrifera: Implications for natural forest management in Ghana. Nairobi: African Academy of Sciences.

Brammer, H. (1962). Soils. In J. B. Wills (Ed.), Agriculture and land use in Ghana, Ministry of Agriculture, Accra, Ghana (pp. 84-114). London: Oxford University Press.

Brokaw, N. V. L., \& Scheiner, S. M. (1989). Species composition in gaps and structure of a tropical forest. Ecology, 70, 538-541. http://dx.doi.org/10.2307/1940196

Capers, R. S., Chazdon, R. L., Brenes, A. R., \& Alvarado, B. V. (2005). Successional dynamics of woody seedling communities in wet tropical secondary forests. Journal of Ecology, 93, 1071-1084. http://dx.doi.org/10.1111/j.1365-2745.2005.01050.x

Colwell, R. K. (2006). EstimateS: Statistical estimation of species richness and shared species from samples. Version 8.0. User's Guide and Application. http://purl.oclc.org/estimates

Cornell, J. H. (1978). Diversity in tropical rain forests and coral reefs. Science, 199, 1302-1310.

http://dx.doi.org/10.1126/science.199.4335.1302

D’Oliveira, M. V. N., \& Ribas, L. A. (2011). Forest regeneration in artificial gaps twelve years after canopy opening in Acre State Western Amazon. Forest Ecology and Management, 261, 1722-1731. http://dx.doi.org/10.1016/j.foreco.2011.01.020

Denslow, J. S. (1995). The effects of disturbance on tree diversity in tropical rain forest: The density effect. Ecological Applications, 5, 962-968. http://dx.doi.org/10.2307/2269347

Dickinson, M. B., \& Whigham, D. F. (1999). Low rates of natural regeneration of Mahogany in felling gaps after selective logging in Quintana Roo, Mexico. International Forestry Review, 1, 35-39.

Dupuy, J. M., \& Chazdon, R. L. (2006). Effects of vegetation cover on seedling and sapling dynamics in secondary tropical wet forests in Costa Rica. Journal of Tropical Ecology, 22, 65-76. http://dx.doi.org/10.1017/S0266467405002890

FAO (1983). Logging and transport in steep terrain. FAO Forestry Paper 14, Rome: Food and Agriculture Organization.

Fredericksen, T. S., \& Mostacedo, B. (2000). Regeneration of timber species following selection logging in a Bolivian tropical dry forest. Forest Ecology and Management, 131, 47-55.

http://dx.doi.org/10.1016/S0378-1127(99)00199-1

Fredericksen, T. S., \& Pariona, W. (2002). Effect of skidder disturbance on commercial tree regeneration in logging gaps in a Bolivian tropical forest. Forest Ecology and Management, 171, 223-230. http://dx.doi.org/10.1016/S0378-1127(01)00767-8

Gotelli, N., \& Colwell, R. K. (2001). Quantifying biodiversity: Procedures and pitfalls in the measurement and comparison of species richness. Ecology Letters, 4, 379-391. http://dx.doi.org/10.1046/j.1461-0248.2001.00230.x

Gourlet-Fleury, S., Favrichon, V., Schmitt, L., \& Petronelli, P. (2004). Ecology and management of a neotropical rainforest: Lessons drawn from Paracou, a long-term experimental research site in French Guiana (pp. 254-280). Paris: ECOFOR and Elsevier.

Hall, J. B., \& Swaine, M. D. (1981). Distribution and ecology of vascular plants in a tropical rain forest vegetation of Ghana (383p). Geobotany Series 1, The Hague: Dr. W. Junk Publishers. http://dx.doi.org/10.1007/978-94-009-8650-3

Hawthorne, W. D. (1993). Forest regeneration after logging: Findings of a study in the Bia South Game Production Reserve, Ghana (52p). ODA Forestry Series No. 3, Kent: Natural Resources Institute.

Hawthorne, W. D. (1995). Ecological profiles of Ghanaian forest trees (319p). Tropical Forestry Papers 29, Oxford: Oxford Forestry Institute.

Heinrich, R. (1978). Mountain forest roads and harvesting (pp. 1-154). Technical Report of the Second FAO/Austria Training Course, Austria 1978, Rome: FAO.

Honu, Y. A. K., \& Dang, Q. L. (2000). Responses of tree seedlings to the removal of Chromolaena odorata Linn. in a degraded forest in Ghana. Forest Ecology and Management, 137, 75-82. http://dx.doi.org/10.1016/S0378-1127(99)00315-1

McCune, B., \& Mefford, M. J. (1997). PC-ORD for Windows: Multivariate analysis of ecological data, version 4. Gleneden Beach, OR: MjM Software.

Putz, F. E. (1983). Treefall pits and mounds, buried seeds, and the importance of soil disturbance to pioneer trees on Barro Colorado Island, Panama. Ecology, 64, 1069-1074. http://dx.doi.org/10.2307/1937815

Sheil, D., \& Burslem, D. F. R. P. (2003). Disturbing hypotheses in tropical forests. Trends in Ecology \& Evolution, 18, 18-26. http://dx.doi.org/10.1016/S0169-5347(02)00005-8

Sheil, D., Burslem, D. F. R. P., \& Alder, D. (1995). The interpretation and misinterpretation of mortality rate measures. Journal of Ecology, 83, 331-333. http://dx.doi.org/10.2307/2261571

Sheil, D., Jennings, S., \& Savill, P. (2000). Long-term permanent plot observations of vegetation dynamics in Budongo, a Ugandan rain forest. Journal of Tropical Ecology, 16, 765-800. http://dx.doi.org/10.1017/S0266467400001723

Sist, P., \& Nguyen-The, N. (2002). Logging damage and the subsequent dynamics of a dipterocarp forest in East Kalimantan (19901996). Forest Ecology and Management, 165, 85-103. http://dx.doi.org/10.1016/S0378-1127(01)00649-1

Sist, P., Fimbel, R., Nasi, R., Sheil, D., \& Chevallier, M. H. (2003). Towards sustainable management of mixed dipterocarp forests of South East Asia: moving beyond minimum diameter cutting limits. Environmental Conservation, 30, 364-374. http://dx.doi.org/10.1017/S0376892903000389

Swaine, M. D., \& Agyeman, V. K. (2008). Enhanced tree recruitment following logging in two forest reserves in Ghana. Biotropica, 40, 370-374. http://dx.doi.org/10.1111/j.1744-7429.2007.00386.x

Swaine, M. D., \& Hall, J. B. (1988). The mosaic theory of forest regeneration and the determination of forest composition in Ghana. Journal of Tropical Ecology, 4, 253-269. http://dx.doi.org/10.1017/S0266467400002819

Swaine, M. D., Agyeman, V. K., Kyere, B., Orgle, T. K., Thomson, J., \& Veenendaal, E. M. (1997). Ecology of forest trees in Ghana (76p). ODA Forestry Series No. 7, London: Overseas Development Administration.

Swaine, M. D., Lieberman, D., \& Putz, F. E. (1987). The dynamics of tree populations in tropical forest: A review. Journal of Tropical Ecology, 3, 359-366. http://dx.doi.org/10.1017/S0266467400002339

Ter Steege, H. (1996). Winphot 5: A program to analyze vegetation indices, light and light quality from hemispherical photographs. Tropenbos-Guyana Reports 95/2, Georgetown: Tropenbos-Guyana Programme.

Van Rheenen, H. M. P. J. B., Boot, R. G. A., Werger, M. J. A., \& Ulloa, M. U. (2004). Regeneration of timber trees in a logged tropical forest in north Bolivia. Forest Ecology and Management, 200, 39-48. http://dx.doi.org/10.1016/j.foreco.2004.06.024 